\title{
Formation of Ethnic Identiy of the Indigenous Peoples of the North in Arts and Crafts on the Example of Bone Carving
}

\author{
Natalia M. Libakova and Ekaterina A. Sertakova* \\ Siberian Federal University \\ 79 Svobodny, Krasnoyarsk, 660041, Russia
}

Received 18.08.2014, received in revised form 25.10.2014, accepted 15.02.2015

A problem of forming ethnic identity is especially important for representatives of the indigenous peoples, as in the current climate of global transformations it is getting increasingly difficult to maintain the uniqueness of traditional cultures under the influence of dominating ones. But at the same time within the culture itself there are many mechanisms, which help to build and maintain ethnic identity. One of such mechanisms is the arts and crafts. The basis for the analysis have been the works of the Krasnoyarsk Territory bone carvers. The authors of the paper open the possibility of this kind of art in the preservation of traditional cultural values, formation of ethnic identity of the indigenous peoples in modern times.

Keywords: indigenous peoples, indigenous small-numbered peoples of the North, ethnic identity, culture studies, arts and crafts, bone carving.

Research area: culture studies, art history.

The analysis has been made as a part of research funded by the Krasnoyarsk Regional Fund, acting to support scientific and technological activities. The work also corresponds to the thematic plan of SibFU according to the instructions of the Ministry of Education and Science of the Russian Federation.

Currently, the phenomenon of "identity" is studied in various areas of social and humanitarian sciences, primarily in the field of psychological, sociological, gender, culture and political science, ethnology, economics, and many others. Researchers' interest in the phenomenon of "identity" is due to its significance in the formation of identity, which determines important characteristics of its relationship to itself, to others, to society, defining its "Self) (Arinushkina, 2004: 42).

Active theoretical and empirical study of the problem of identity began in the last decades of the $20^{\text {th }}$ century. Many researchers are working in this field nowadays, e.g. G.M. Andreeva, N.L. Ivanova, T.V. Rumiantseva, A.V. Mikliaeva, I.S. Kletsina, O.V. Zakharova, N.S. Arinushkina, V.S. Malakhov, V.A. Iadov, K.A. Svasian, J. Berry, P. Knight, G. Barkuzen, V. Clerc, E.L. Sweet, M. Chakars.

(c) Siberian Federal University. All rights reserved

* Corresponding author E-mail address: sertachok@mail.ru 


\section{Phenomenon of ethnic identity and mechanisms of its formation}

Ethnic identity is formed and defined by various ethnic and social dominants, which are acquired during personal socialization. First and foremost, they are formed in the process of assimilating people's own culture and culture of other nations, in the process of studying history. Belonging to a certain ethnic group is one of the facets of social identity. In modern Russian psychology, the study of ethnic identity focuses on the changes that occur in it in this era of radical social transformations (Stefanenko, 2003).

Also, the study of ethnic identity is carried out within the framework of acculturation and cultural conflict theory. The authors stress that ethnic identity becomes meaningful only in situations where several ethnic groups are in close interaction within a certain period of time. For ethnically homogeneous society it is a meaningless concept. Ethnic identity can be understood as an aspect of acculturation, in which the main focus is on the person and how he/she interacts with his/her ethnic group, which is a part of society as a whole (Mikliaeva, Rumiantseva, 2008).

N.S. Arinushkina examines ethnic identity as the experience of relationships between "Self" and ethnic environment, its equivalence with one ethnic community and separation from others. The researcher, referring to J. Hoffmann, describes the variations of ethnic identity: racial, biological, climatic and socio-cultural. Cultural identity is seen as close to ethnic identity (Arinushkina, 2004). This type of identity is a conscious acceptance by human of certain cultural norms, rules, patterns of behavior, value orientations , language, perception of "Self" from the perspective of such cultural characteristics that are accepted, supported by and implemented in this society. Cultural identity is expressed in self-equivalence to the cultural constituent image of a given society.
M.M. Predovskaia analyzes cultural identity as a complex multicomponent phenomenon (2009). The scientist suggests that a balanced cultural identity includes professional, social, geographical, ideological, linguistic, and biological aspects. Moreover, this harmonious whole can not imply any dominant ethnic or national component.

Based on the theory produced by I.V. Malygina, D.G. Lavrinov's research (2008: 24-25) refers to the study of ethnic and cultural identity, understood as a complex social and psychological phenomenon, the content of which is the realization by the individual of a communion with the local group on the basis of the shared culture, as well as awareness by the communion of its unity on the same grounds, the psychological experience of this community, and individual and collective forms of its manifestation.

In the analysis of the phenomenon and concept of "identity" and its types, a question about the mechanisms of its formation has been raised anyway. This process has no end point, although some researchers have noted that completed complex identity is formed "by the end of youth and the beginning of middle age" (Guboglo, 2003:41). During lifetime a person is exposed to various external factors that affect the change of identity. The phenomenon of "identity crisis", that is the state of a person, who has lost self-image, was originally analyzed in the field of psychiatry, then American psychoanalyst E. Eriksontransferred the conceptintodevelopmental psychology, showing that identity crisis is normal for human development. Social transformations, change of economic structure, political system and etc., cause imbalance of identities that can occur at any age and restart self-identification mechanism, i.e. the definition of the relationship between "self" and others (Guboglo, 2003:72 ).

V.S. Malakhov (2007) emphasizes the possibility of conscious construction of identity, 
in particular, he considers the construction of national identity. The researcher notes that this process is a necessity for democratic actors.

Researcher Iu. Cherniavskaia (2008), referring to the topic of ethnic identity, says that there is a "turning point" in understanding the basics of this phenomenon. If originally the mechanism for the formation of ethnic identity was linked to kinship (primordialist approach), but at the present stage of development of scientific knowledge scientists are likely to take into account the fact that the source of its formation is cultural phenomena (folklore, art, etc.). Hence the attention of researchers should be directed not to the study of the genome, but to rituals, customs and folk life and art as a certain identity constructs (constructivist approach).

According to the scientist, ethnic identity has a mythological nature (Cherniavskaia, 2008: 201). Mythological worldview is set by characteristics of an ethnos (land inhabited by the people, language, historical consciousness, values ), which transfers them to future generations.

K.V. Reznikova supports views of Iu. Cherniavskaia and V.S. Malakhov on the nature of an ethnic group. She also expresses the view that globalization, increasing in recent decades, leads to heterogenization of the world. That means there is a "cultural renaissance" of individual ethnic groups, their appeal to their history, traditions, art and ethnic identity. In this case, ethnicity is understood as a "mental construct", i.e. not as objectively existing signs, but as subjective perceptions of them. According to the researcher, the grounds of ethnic identity may be located outside the community as well as within it. Most often, the formation of ethnic identity occurs as unconscious individual process. In the course of socialization human masters cultural institutions as granted, and through them a person gets identification.
Researcher N.N. Seredkina notes that the effective means of formation of ethnic identity are the cultural and semiotic practices, means of art. Artworks are an important "social field", which represents the ethnic worldview and attitude. Artworks are an expression of "ethnic picture of the world".

\section{Methodological approaches in the study of ethnic identity}

In contemporary cultural studies hermeneutical approach is a priority (Otiutsky, 2003:347). This research direction is adequate to processes occurring in the world today, in particular, population migrations, ant it increases the intensity of economic, political and cultural contacts between the representatives of different countries and ethnic groups as a result of globalization. The processes mentioned above have a great influence on the formation of ethnic identity and the representatives of indigenous cultures are especially susceptible to this influence.

Relevance of the hermeneutic approach stems from the fact that researchers, supporters of this approach, consider the studied culture not as a passive object, but as an active one. In this case study is a dialogue of equals, in which priority is given to understanding the other. Traditionally, the founders of the hermeneutic direction are $\mathrm{C}$. Geertz (2004) and V.A. Turner. However, long before them, Sir E.E Evans-Pritchard assumed study of culture as a dialogue of equals, whose main purpose is both adequate understanding and interpretation of another culture, rather than an explanation and discovery of universal laws, common to all cultures.

The method of "interpretation" (which also has the name of "cultural analysis"), including an explanation of the values enshrined in the symbolic forms, awards the researcher with an active role as a mediator rather than bystander. 
The most important method of field research is that "participant observation", implying impassive, aimed at perfect objectivity observation of life of representatives of the culture under study, is replaced by the "supervisory participation". The latter presumes emotional contact, experience, participation and observation "of participation of themselves and others in the ethnographic process". The study obtains the character of ethnographic dialogue, where "self" and "other" are inseparable (Lurie, 1997:97).

Study of the possibilities of art in the formation of ethical identity requires the involvement of art study methods and approaches. Today, along with classic traditional art study approaches to the analysis of works of art, there are also some alternative approaches, in particular, the procedure of philosophical and art analysis, developed and actively used by Russian scientists V.I. Zhukovsky and N.P. Koptseva (Krasnoyarsk), D.V. Pivovarov (Ekaterinburg). For the present study some key points of the methodology of fine arts are important too:

1. A work of art is a visual text that is similar to the verbal text, because one may read it through philosophical and art analysis, based on the application of general scientific research methods - analysis, synthesis, formalization, analogy, extrapolation, induction, deduction, and some other methods. This approach to the analysis of works of art can overcome the subjectivity in the evaluation of the content and allow reading the content of visual text (Zhukovsky, Koptseva, Pivovarov, 2006; Zhukovsky, Koptseva, 2004).

2. In a work of art as a visual text there are three levels of meaning: A) cosmocentric level, expressing global ideas about the meaning of life, relationships between human and God, about human's place in the universe and the like; B) sociocentric level, expressing the specificity of actual historical situation, meanings, topical for the time when a work of art was created;
C) egocentric level, expressing the subjectivity of an artist, meanings that were significant for the author of works and personal experiences (Zhukovsky, Koptseva, Pivovarov, 2006; Zhukovsky, Koptseva, 2004).

Identifying of these levels of meaning is only possible in the process of sequential analysis of the real existence of a work of art. The order of steps is determined by the specific levels of signs in an artwork. The analysis begins with an understanding of index signs, the next stage deals with iconic signs and final with the reading of symbolic signs. Such step-by-step study of signs in the artwork allows to read it as a holistic visual text, identify and understand the meanings inherent in the text.

Modern art studies show that the works of art render not only personal subjective views of an author, but also other broader meanings - general cultural, commom for all mankind, so it gives reason to use the philosophical and art analysis to identify the identity of a particular culture, as well as considered a work of art as a factor influencing the formation of ethnic identity (Sweet, Chakars, 2010; Kistova, 2013; Koptseva, Nevol'ko 2012; Reznikova, 2013; Solov'iova, 2009; Amosov, A.Ie., Koptseva N.P., Libakova N.M., Reznikova K.V., Sertakova K.V., Pimenova, N.N., Kistova A.V., 2012, etc.).

\section{Formation of ethnic identity in arts and crafts (bone carving)}

Traditional form of creativity for the indigenous peoples of the North remains arts and crafts. As an ancient art form of the North, until the beginning of the $20^{\text {th }}$ century it was of a mass character. Representatives of the northern ethnic groups made clothes of deerskin, profusively decorating it with ornament and beads, carved wood for patterned household items, and they were especially skillful in bone carving. So almost all men - hunters, fishermen, and herders were 
engaged in carving in their spare time or during bad weather. Topics of carved bone images for centuries reflected the lifestyle of ethnic groups, their beliefs (animism, shamanism), portrayed the specificity of the North and its inhabitants.

During the Second World War and after it the art of bone carving considerably weakened its positions, because life of the indigenous peoples of the North changed radically during this period of time. Traditional forms of farming, traditional beliefs, native language and art in connection with new challenges set by the state were absorbed by a "big culture" (Berry, Dasen, Purtinga, Sigall, 2007).

At the end of the $20^{\text {th }}$ century the "discovery" of the North happens again, the indigenous peoples seek to revive and preserve the uniqueness of their culture, to find their own place in a diverse picture of the world by identifying their ethnic identity. In this situation, they needed cultural concepts, capable of uniting ethnic groups, becoming the signs expressing ethnic identity. Therefore a major role in this issue is played by arts and crafts.

Certainly, civilization processes have changed the opinion about decorative and applied arts. Today most of them are referred to as souvenirs rather than folk art. The goal of making these things is more inclined to tourists' demand and they progressively lose their original "sacred" sense. However, for the indigenous peoples they remain relevant and stay in demand even today.

Many researchers, such as J.B. Shetler, U. Popova, G.A. Khlopachev, Ie.Iu. Giria, I.N. Ukhanova, V.A. Subbotina, S.V. Rogachev, Ie.S Musina, V.Kh. Ivanov, V.G. Zavarzina and others, believe that the arts and crafts, and in particular the works of carved bone reflect the worldview of the people, important for their existence principles.

Works of arts and crafts not only store a spiritual experience of previous generations, but also embody the collective and nongenetic memory of an ethnos. This memory for any nation is connected with the idea of the worldview, of human, of his/her place in the society and universe as a whole. The result is that each piece of decorative art is an important mechanism influencing the formation of ethnic identity.

The samples of arts and crafts can be represented by works of masters - bone carvers. In Russia the most famous centers of bone carving art are located in the Republic of Sakha, Udmurtia, Arkhangelsk Oblast, Tyumen Oblast, Nenets, Khanty-Mansiysk and Chukotka Autonomous Okrugs, and in Tobolsk. However, special attention of researchers was drawn to the relatively recent bone carving art school in Taimyr, which faces a significant challenge; it doesn't only have to revive the ancient craft, but also to make it the brand of the territory, the visual identification for Taimyr for both Russia and other countries.

The revived art of bone carving on the Taimyr Peninsula has just begun to develop so far. Skills needed to work with bone were almost completely lost by the representatives of the indigenous peoples of the peninsula across the $20^{\text {th }}$ century. And only during the last decade, these skills have started to revive as a specific art for the area. While 15 years ago only two Taimyr masters were known' they are O.A. Marchenko and V.S. Taranets, nowadays more than two hundred professional artists, including 184 carvers - representatives of the indigenous peoples of the North, keep the tradition of folk art. They are concentrated in a few centers - Norilsk and Dudinka cities and in rural areas of Khatanga, Karaul and Kaerkan.

The most famous masters of carving art are N.V. Laptukov, N.M. Kirgizov, A.N. Chunanchar, V.I. Batagai, D.V. Chuprin, V.A. Beti, P.Kh. Vango, V.S. Kirgizov, A.V. Sigunei. Their very creative skills define the vector of bone 
carving development in Taimyr, determine the themes and style of work.

Taimyr bone carvers' works are mainly small-scale sculpture; engraving, fretwork and relief carving are much rarer. Favorite materials for creativity are antler and mammoth tusk (Ie.S. Musina, 2011).

Mammoth is the most valuable and, unfortunately, endangered material produced in smallvolumesinpermafrostregions. Homogeneity of its bone tissue gives the opportunity to work it up in the most fastidious fretwork technique. Antlers of reindeer are more heterogeneous and complex for processing, but as the material they are more readily available. Thus, A.N. Chunachar creates works of antlers, while N.M Kirgizov prefers mammoth tusk.

However, for the true masters the availability of the material is always relegated to the background, in their opinion, the most crucial is the essence, which the material carries and memory which it stores. Let us cite, for example, the words of the famous Tobolsk carver M.V. Timergazeev: "Mammoth tusk remembers a mammoth lying in the ground, and antler - a reindeer to which it once belonged" (Ie.S. Musina, 2011). Hence, the main task of the master is not just the mastery in applying carving and sharpening tools, but creation of a special look and feel that will help to see the material in its inner essence, orient the master's hand to the right direction in order to manifest this essence in a suitable form.

In addition, the Taimyr masters often combine bone or antler with other natural materials (deerskin, different types of wood, stones, feathers, etc.). This is one of the distinguishing features of the Taimyr bone carving.

Works of Taimyr bone carvers reproduce several stable topics: 1) everyday life and culture of the peoples of Taimyr; 2) tundra and its inhabitants; 3) Taimyr myths, tales and legends;
4) shamanism as a traditional belief of the indigenous peoples of the North.

1) Everyday life and culture of the peoples of Taimyr is a very common theme in smallscale sculptures. All artistic products have this distinguished ethnographic accuracy; each of the five peoples living on the peninsula is easily guessed by specific characteristics and occupation reflected in the piece of art. Characteristic features of the terrain and weather conditions also leave no doubt. People at work take a prominent place in bone sculptures. People are portrayed during hunting, fishing, in the camp, in familiar, everyday life.

For example, the work "Taimyr Traditional Crafts" by N.M. Kirgizov demonstrates traditional occupations of a person living on the peninsula - fishing, hunting, bird hunting, reindeer husbandry. All these occupations are similar in their image - each of them presents a complete scene where a person is included in the natural space. Thus, one of the most noteworthy features of northern ethnic groups reveals and it is the inextricable link between human and the environment.

The interesting thing is that the scenes are arranged vertically, setting a hierarchy of human occupations. Thus, more dignified and honorable occupation in northern peoples' life is reindeer husbandry.

Work "Dolgans' Everyday Life" of the same master demonstrates people's daily life told as a whole story. First of all, the structure of the work gives an idea of the structure of the universe; it shows two levels - the human (average world) and the underground (lower world). Upper level of the world is invisible to the human eye. People are presented doing their traditional deeds: they hunt, fish using nets, herd reindeer. Also the master carved traditional dwelling of these people - tent, around which they are busy with the housework. 


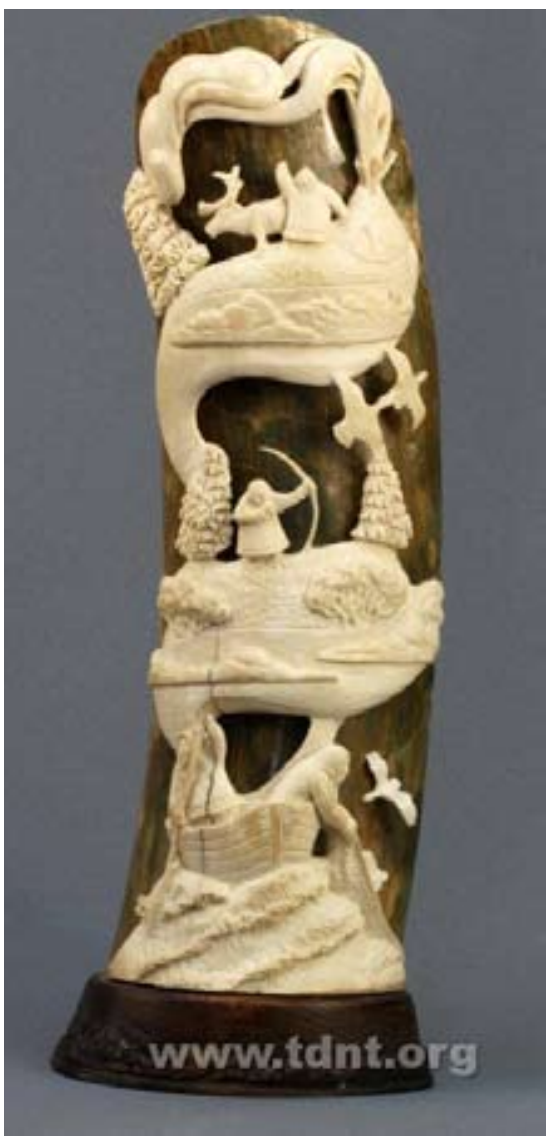

Fig. 1. Kirgizov. Taimyr Traditional Crafts, 2011. Mammoth tusk, beech

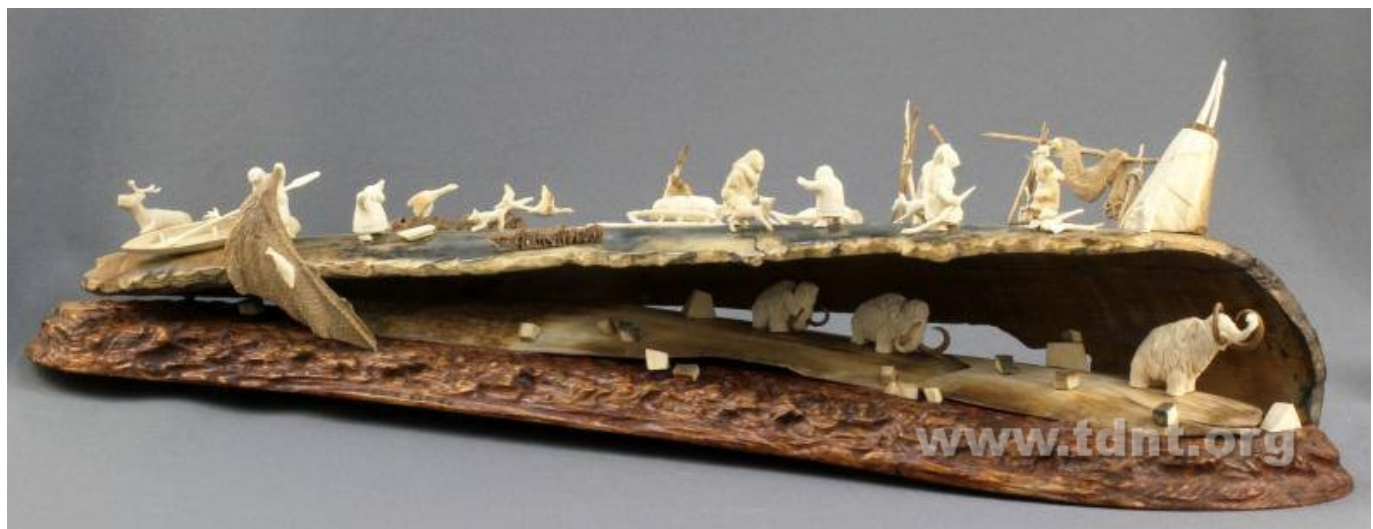

Fig. 2. Kirgizov N.M. Dolgans' Everyday Life, 2011. 170x125x570, Mammoth tusk, beech

More interesting one is the image of lower world, which shows the mammoths. There is a legend about the creation of the earth by the deity Ngo. This legend tells the story of how the earth became inhabited by humans, birds, fish, animals, as well as mammoths. But mammoths brought a lot of problems when they moved, the earthquake occurred, when they foraged about for food and 
dug the earth, the mountains appeared. Therefore Ngo placed mammoths underground, making them its support. Mammoths are still revered as sacred underground animals, which secure peace of people.

- a chum (tent), around which there are people, busy with their household chores.

Thus, work "Dolgans' Everyday Life" in addition to making household sketches tells a tale of ordinary occupations of the northern people, demonstrates the harmonious immanence of this activity in the history of the world, the system of the universe.

2) Tundra and its inhabitants. Works devoted to this subject are filled with scenes from the life of the Taimyr tundra. Basically masters

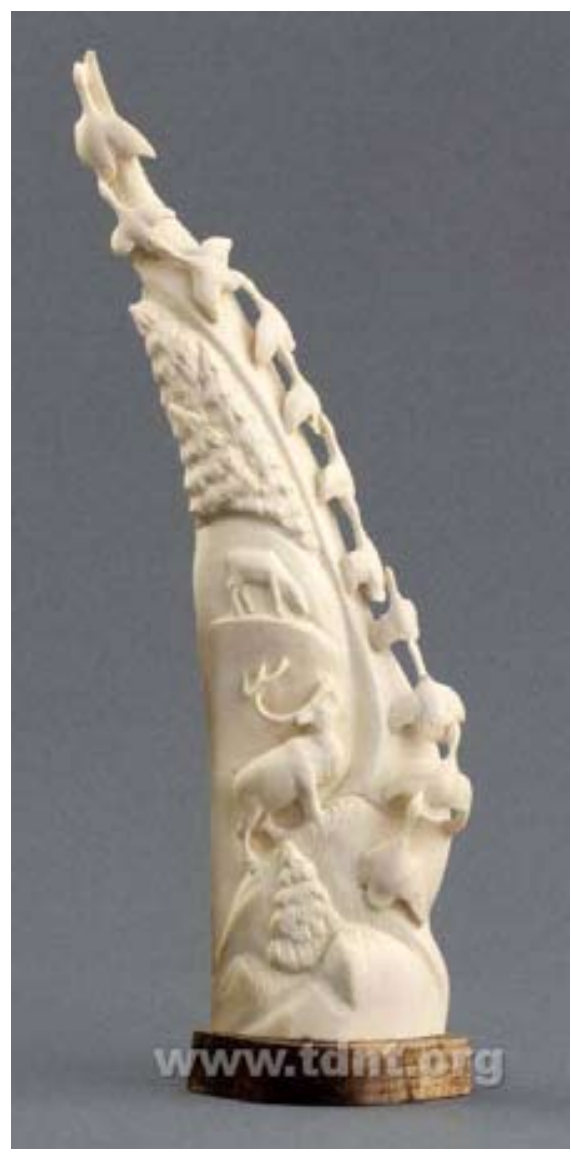

Fig. 3. Kirgizov N.M. Spring, 2008. 260x54x60. Mammoth tusk, wood prefer the image of individual figures from fauna: partridges and deer, owls and geese, ancient mammoths and shaggy musk oxen, arctic foxes, wolves and bears.

Work of N.M. Kirgizov "Spring" is a story, dedicated to the long-awaited and very brief on the territory of the North season. Spring is traditionally seen as a time of rebirth and awakening of nature and all living things. The composition of this work is full of dynamics, striving upward toward the sun, which gives life: it is read in the lines of a raised deer head, gazing up the tops of fir trees, a flock of flying birds, the movement of which is unifying the entire composition and linking everything and everyone together.

3) Taimyr myths, tales and legends. Images from myths, legends, tales are characteristic of all indigenous peoples. This theme is most often found in the works of carving art. Such works most clearly express ethnic characteristics of a particular culture. Most often for these works are images of legendary heroes, sacred animals, spirits, cosmogony and cosmology.

Made in the technique of small plastic "Mother deer" by A.N. Chunanchar opens favorite for bone carvers topic "deer", but this work is not quite traditional. Figure of a doe made is of barely processed antler and therefore looks massive and great. In comparison with it human figures, dogs and birds are extremely small. This shows the value of the deer for northern peoples: literally everything relies on deer. Vertical bands, made of suede, symbolize on the one hand, rays of the sun, covering the entire space of the composition, stretching over birds, animals and humans. On the other hand, these lines resemble the shape of a conventional dwelling of the northern peoples - chum, which is made of reindeer skin. Also this works visualizes a legend about the origin of the northern peoples from deer. The traditional name of the Evenki 


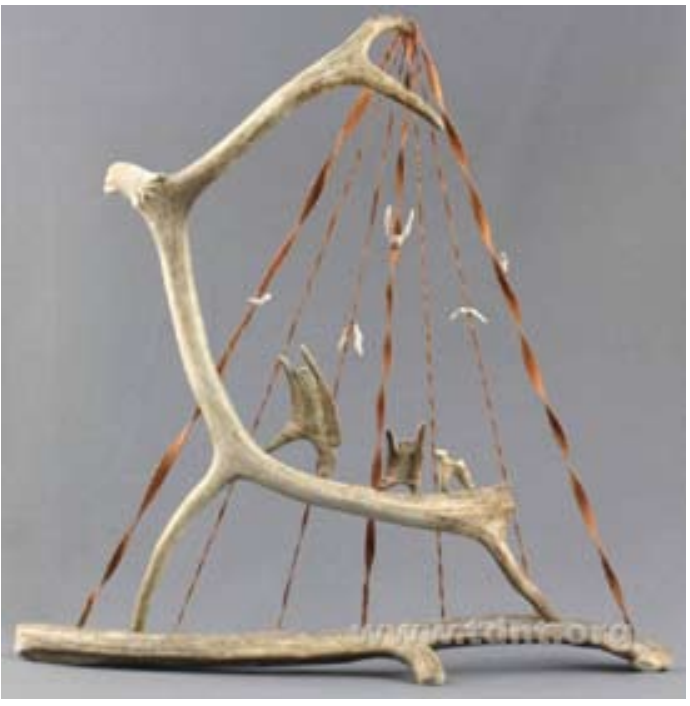

Fig. 4. Chunanchar A.N. Mother Deer, 2010. Deer antler, suede

ethnic group - "reindeer people", for example, has survived to the present days.

Interpretation of a bird archetype implies a deep philosophical meaning. In the symbolism and mythology of the indigenous peoples birds have a positive value. Image of a bird is associated with another legend about the origin of life on the earth. According to the legend, the bird went down into the sea and picked out a shed of land, which later became the basis for the universe. Until today, this symbol has not lost its value, birds are worshipped as before. Thus, the red-breasted goose image can be found on the flag of Taimyr, and on the coatof-arms of Evenkia there is a white-throated diver. The work by N.M. Kirgizov "Kara Kaas Kuta" (Spirit of a black goose) disclosed a liaison function of birds. According to the concepts of the North peoples, the world has a three-part structure. The bird has the ability to move between these levels, emphasizing their unity and unbreakable bond. Image of a bird in such a way is the image of spirit, aspiring to heaven.

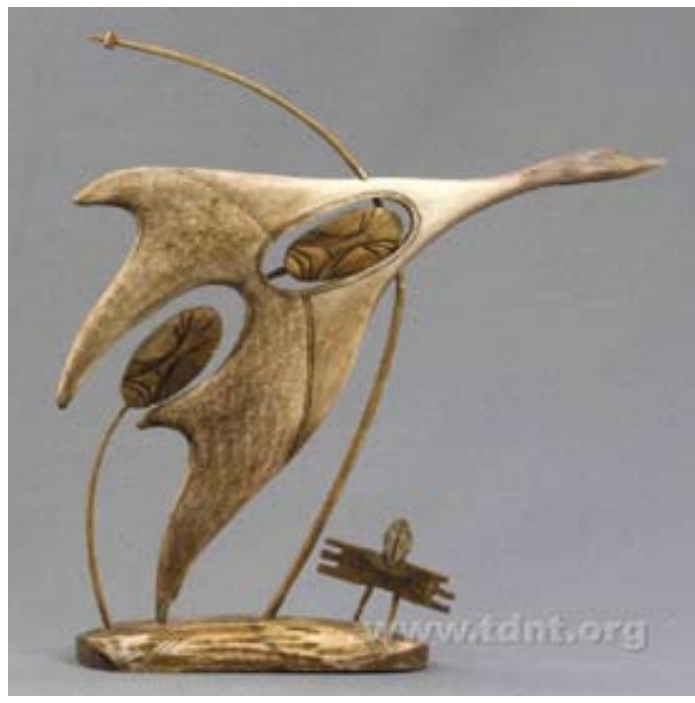

Fig. 5. Kirgizov N.M. Kara Kaas Kuta (Spirit of a black goose), 2009. 230x48x138. Deer antler, wood stain

Similar images can be found in the work of "Old-man Stories". Here the boat, on which we see a representative of the northern peoples, is intricately decorated with zoomorphic sails. Deer and spirit-bird protect human, indicate his life path.

Undoubtedly, once similar deer and bird images had ritual character.

4) Shamanism as a traditional belief of the indigenous peoples of the North.

Subject of shamanism is presented as separate from life of the peoples of the North, since a shaman is not just a man, he is a minister of religion, a mediator between the human and spirit worlds. The work by N.V. Laptukov a shaman is depicted during seances, in full dress, his clothes is covered with numerous protective amulets, the chief of which is a medallion on his chest with a deer on it. This piece of art shows exaggeratedly large hands of the shaman, who strikes the drum, thereby tuning to the sound of cosmic rhythm. The shaman is caught during the peak of the action, he is in ecstasy, the moment of separation of 


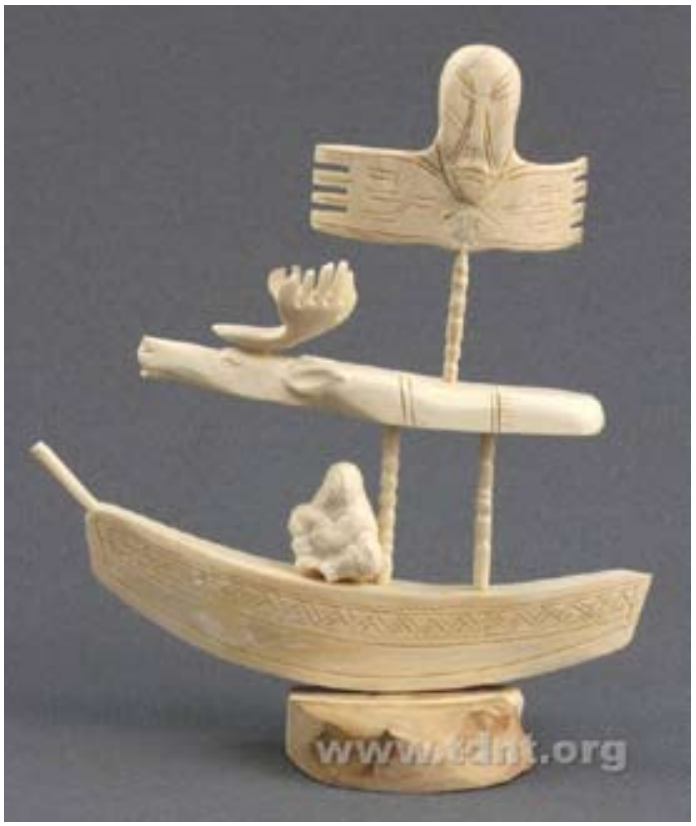

Fig. 6. Kirgizov N.M. Old-man Stories, 2009. $122 \times 55 \times 105$. Mammoth tusk

body and spirit of the shaman is rendered. The image of the shaman's spirit resembles in its contours the figure of a bird that has the ability to move in all three spaces of the universe. Thus, the artist stresses striving of the spirit up, its relationship with the upper world.

\section{Conclusions}

Division of subjects of the skillful bone carvers is rather arbitrary, because in general syncretism is characteristic of traditional culture of the indigenous peoples. Characters of different themes resonate with each other, demonstrating strong ties and combinations.

Visualizing the signs and symbols that express the values of traditional culture, Taimyr bone carvers appeal to what can be called a cultural core of the ethnic groups living on the peninsula (Dolgans, Nenets people, Nganasans,

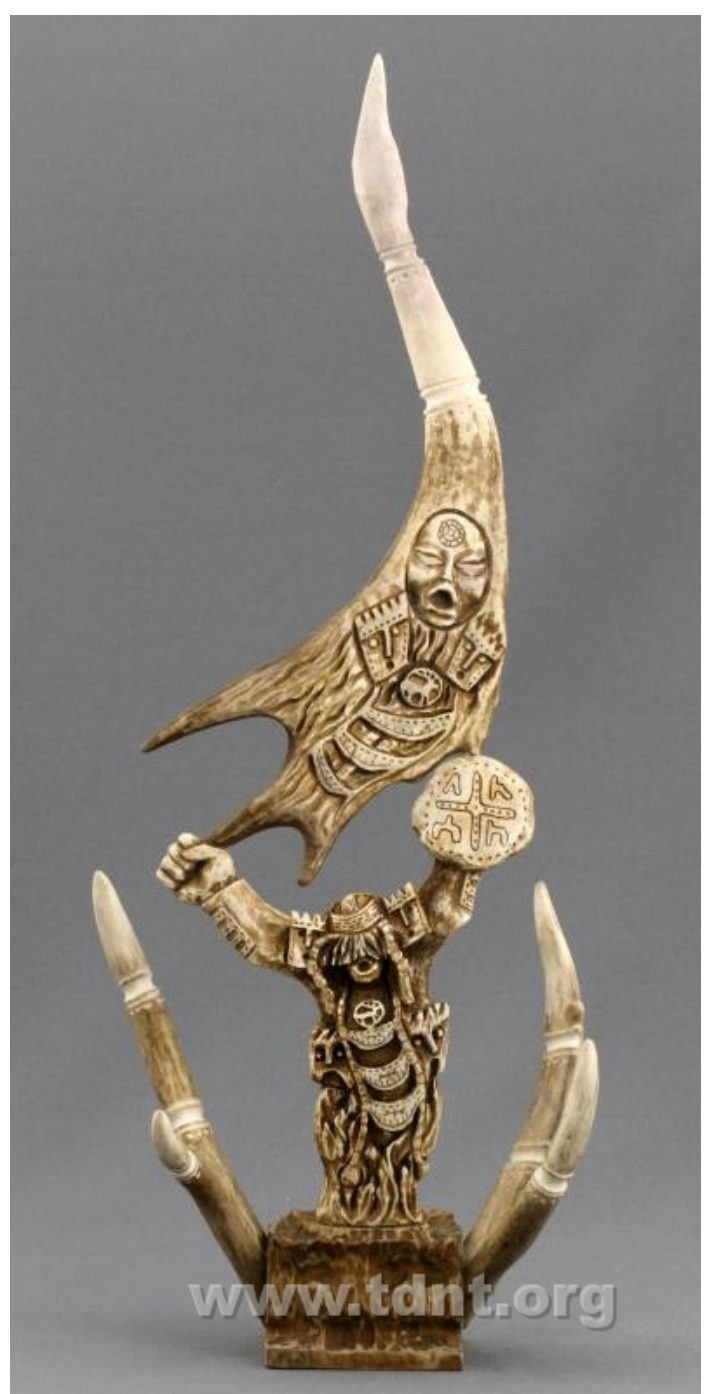

Fig. 7. Laptukov N.V. Spirit of a Shaman, 2010. 460x160x190. Deer antler

Ents and Evenki people). They make a picture of the world, determined in it the place of human, actualize relationship of modern humans with the culture of ancestors. These works of art preserve and transmit a unique insight into human and the world, knowledge of the history of their ethnic group and faith, in such a manner helping to construct ethnic identity. 


\section{References}

1. Abrosimova, A.A., Kaplan, N.I, Mitlianskaya, T.B. Khudozhestevennaia rez'ba po derevu, kosti i rogu [Carving in wood, bone and antler], Moscow, 1998, 192p.

2. Al-Kharrat, E. (2005). Cultural Authenticity and National Identity. Diogenes, 52(2), 21-24.

3. Amosov, A.Ie., Koptseva, N.P., Libakova, N.M., Reznikova, K.V., Sertakova, K.V., Pimenova, N.N., Kistova, A.V. et al. Korennye malochislennye narody Severa i Sibiri v usloviiakh global'nykh transformatsii (na primere Krasnoiarskogo Kraia). Chast' 1. Kontseptual'nye i metologicheskie bazy issledovaniia. Etnokul'turnaia dinamika korennykh malochislennykh nardov Krasnoiarskogo Kraia [The indigenous small-numbered peoples of the North and Siberia under the global transformations (on the basis of the Krasnoyarsk Territory). Part 1. Conceptual and methodological bases of research. Ethno-cultural dynamics of the indigenous small-numbered peoples of the Krasnoyarsk Territory]. Ed.by Koptseva, N.P. Krasnoyarsk, Siberian Federal university, 2012, 640p.

4. Andreev, E.M. (2012). Sotsial'no-kul'turnaia identifikatsiia: metadologicheskie problem issledovaniia i realizatsii [Socio-cultural identitification: methodological problems of research and implementation]. Bulletin of Kazan Technological University, 15(2), 94-98.

5. Arinushkina, N.S. (2004). Ob opredelenii i tipakh identichnosti [On the definition and types of identity]. Mir psikhologii (World of Psychology), 2, 42.

6. Atkinson, P. (2013). Blowing Hot: The Ethnography of Craft and the Craft of Ethnography. Qualitative Inquiry, 19(5), 397-404.

7. Bakhova, N.A., Bukharov, A.V., Viktoruk, Ie.A., Il'beikina, M.I. et al. Novoe budushchee Sibiri: ozhidaniia, vyzovy, resheniia: monografiia [New future of Siberia: expectations, challenges, solutions: monograph]. Krasnoyarsk: Siberian Federal University, 2013.

8. Barkhuizen, G., Klerk, V. (2006). Imagined identities: Preimmigrants' narratives on language and identity. International Journal of Bilingualism, 10(3), 277-299.

9. Batianova, Ie.P., Smolitskii, V.G., Turaev, V.A. (2010). Review on: Tishkov, V.A. Tundra i more. Chukotsko-eskimosskaia rez'ba po kosti [Tundra and sea. Chukchi-Eskimo bone carving] (2008). Etnograficheskoe obozrenie (Ethnographic Review), (5), 184-188.

10. Berry, J.W., Dasen, P.R., Purtinga, A.H., Sigall, M.H. Kross-kul'turnaia psikhologiia. Issledovaniia i primenenie [Cross-cultural psychology. Research and application], Kharkiv, 2007, 560.

11. Bibikov, G.N. (2011). Terminologicheskaia bor'ba za kul'turu: sovremennye podkhody k izucheniiu kul'turnykh protsessov [Terminological struggle for culture: modern approaches to the study of cultural processes]. Observatoriia kul'tury (Observatory of culture), (1), 19-25.

12. Bolin, H. (2000). Animal Magic: The Mythological Significance of Elks, Boats and Humans in North Swedish Rock Art. Journal of Material Culture, 5(2), 153-176.

13. Borodina, A.B. Esteticheskii analiz dekorativno-prikladnogo iskusstva russkogo severa [Aesthetic analysis of arts and crafts of the Russian North]. Summary of Thesis for Candidate of Philosophical Sciences, M., 2012, 26p.

14. Boronoev, A.O. (2010). Problemy dinamiki Sibirskoi identichnosti [Dynamics problems of Siberian identity]. Obshchestvo. Sreda. Razvitie. (Society. Enironment. Development) (TerraHumana), (3), 81-85. 
15. Bystrova, Ie. (2007). Kholmogorskaia rez'ba po kosti [Kholmogory bone carving]. Narodnoe tvorchestvo (Folk art), (3), 60-65.

16. Cherniavskaia, Iu.V. (2008). Identichnost' na fone mifa [Identity against the background of myth]. Antropologicheskii forum (Anthropological forum), 8, 198-226.

17. Fedorova, N.V. (2011). Kostianaia antropomorfnaia skul'prtura so sviatilishcha Ust'-Polui [Bone anthropomorphic sculpture in Ust-Polui sanctuary]. Arkheologiia, etnografiia $i$ antropologiia Evrazii (Archaeology, ethnic geography and anthropology of Eurasia), 1, 77-81.

18. Fenelon, J.V., Murguia, S.J. (2008). Indigenous Peoples: Globalization, Resistance, and Revitalization. American Behavioral Scientist, 51(12), 1656-1671.

19. Fisher, L. (2012). The Art/Ethnography Binary: Post-Colonial Tensions within the Field of Australian Aboriginal Art. Cultural Sociology, 6(2), 251-270.

20. Gashimova, L.P., Sterkhova, N.S. (2010). Iskusstvo rez'by po kosti kak sredstvo esteticheskogo vospitaniia studencheskoi molodezhi krainego severa [Bone carving art as a means of aesthetic education of students of the Far North]. Bulletin of Shadrinsk State Pedagogical Institute, 4(9), 72-76.

21. Geertz, K.G. Interpretation of cultures. Moscow, ROSSPEN, 2004, 560p.

22. Graburn, N.H. (2004). Authentic Inuit Art: Creation and Exclusion in the Canadian North. Journal of Material Culture, 9(2), 141-159.

23. Greaves, T. (2002). Examining Indigenous Rights to Culture in North America. Cultural Dynamics, 14(2), 121-142.

24. Guboglo, M.N. Identifikatsiia identichnosti: etnosotsiologicheskie ocherki [Identification of identity: ethnosociological essays]. Moscow: Nauka, 2003, 763p.

25. Guzenina, S.V. (2012). Kul'turnaiia samobytnost' v fokuse sovremennykh nauchnykh issledovanii [Cultural identity in the focus of current research]. Analitika kul'turologii (Analytics of cultural studies), (24), 109-112.

26. Iadov, V.A. (1995). Sovremennaia situatsiia v Rossii. Sotsial'nya i sotsial'nopsikhologicheskie mekhanizmy formirovaniia sotsial'noi identichnosti lichnosti [Current situation in Russia. Social and socio-psychological mechanisms for forming social identity of the individual]. Mir Rossii (World of Russia), 3-4, 158-181.

27. Ivanov, V.Kh. Iakutskaia rez'ba po kosti [Yakut bone carving], Moscow, 1979, 109p.

28. Ivanova, N.L., Rumiantseva, T.V. Sotsial'naia identichnost': teoriia i praktika [Social identity: theory and practice]. Moscow, 2009, 456p.

29. Ivchik, N. (2011). Budushchee nachinaetsia segodnia [The future begins today]. Evenkiiskaia zhizn' (Evenki life), (39), 9.

30. Karataieva, N.F. (2010). Istoriia kholmogorskoi rez'by po kosti [History of Kholmogory bone carving]. Iskusstvo i obrazovanie (Art and education), (4), 12-17.

31. Karpova, N.P. (2011). Issledovanie sokhraneniia i razvitiia kul'turnogo naslediia korennykh narodov respubliki Sakha (Yakutia) [Study of preservation and development of cultural heritage of the indigenous peoples of the Sakha Republic (Yakutia)]. Sovremennye issledovaniia sotsial'nykh problem (Modern studies of social problems), 5(1), 273-275.

32. Khlopachev, G.A., Giria, Ie.Iu. (2010). Sekrety drevnikh kostorezov Vostochnoi Evropy $i$ Sibiri: priemy obrabotki bivnia mamonta i roga olenia v kamennom veke. Po arkheologicheskim $i$ eksperimental'nym dannym [Secrets of ancient bone carvers in Eastern Europe and Siberia: processing 
methods for bone and reindeer antlers in the Stone Age. According to archaeological and experimental data]. St. Petersburg, 143p.

33. Kirgizov, V.S. Chelovek severnogo siianiia: Vasily Kirgizov - kostorez iz Syndassko [A man of the Northern Lights: Vasily Kirgizov - a bone carver from Syndassko]. Dudinka, 2007, 57p.

34. Kirko, V.I., Verkhovets, S.V., Keush, A.V. (2010). Rol' federal'nykh universitetov v formirovanii innovatsionnoi regional'noi struktury (na primere Sibirskogo Federal'nogo universiteta [Role of federal universities in shaping regional innovation structures (on the example of Siberian Federal University)]. Innovatsii (Innovations), (10), 60-64.

35. Kirko, V.I., Zakharova, K.N. (2013). Traditsionnaia khoziaistvennaia deiatel'nost' etnosokhraniaiushchii obraz zhizni [Traditional economic activity - lifestyle, which saves ethnos]. Arktika i Sever (Arctic and North), (12), 24-31.

36. Kistova, A.V. (2013). Metodologicheskoe znachenie "ponimaiushchei germenevtiki" Wil'gel'ma Dil'teia dlia sotsial'no-filosofskogo issledovaniia sovremennykh sotsiokul'turnykh fenomenov [Methodological significance of "understanding hermeneutics" by Wilhelm Dilthey for socio-philosophical study of modern sociocultural phenomena]. Sovremennye problem nauki $i$ obrazovaniia (Modern problems of science and education), (3), 450.

37. Kol'tsova, T.M. (ed.). Narodnaia kul'tura Russkogo Severa [Folk culture of the Russian North]. Arkhangelsk, 1997, 246p.

38. Koptseva, N.P. (2013). Istina v filosofii Platona [Truth in Plato's philosophy]. Filosofiia $i$ kul'tura (Philosophy and culture), 4, 429-436.

39. Koptseva, N.P. (2013). Provedenie eksperimental'nogo prikladnogo issledovaniia mezhkul'turnoi kommunikatsii: focus-gruppy, lichnoe interviiu, anketirovanie, poluchenie ekspertnogo mneniia (na material issledovaniia Krasnoiarskogo kraia) [An experimental applied culture study of intercultural communication: focus groups, personal interviews, questionnaires, obtaining expert opinion (based on the study of the Krasnoyarsk Territory)]. Sovremennye problemy nauki i obrazovaniia (Modern problems of science and education), (3), 410.

40. Koptseva, N.P. (2007). Integratsiia gumanitarnogo obrazovaniia v Sibirskom Federal'nom Universitete [Integration of humanitarian education in Siberian Federal University]. Vysshee obrazovanie segodnia (Higher education today), (4), 6-8.

41. Koptseva, N.P. (2007). Teoriia i praktika innovatsionnoi obrazovatel'noi programmy po esteticheskomu tsiklu distciplin [Theory and practice of innovative educational program for the aesthetic disciplines]. Vysshee obrazovanie segodnia (Higher education today), (12), 9-13.

42. Koptseva, N.P. (2012). Kul'turologicheskaia baza formirovaniia obshcherossiiskoi natsional'noi identichnosti v Sibirskikh regionakh Rossiiskoi Federatsii [Cultural base of all-Russian national identity in the Siberian region of the Russian Federation]. Bulletin of Volgograd State University. Series 7. Philosophy, sociology and social technologies, (3), 11-15.

43. Koptseva, N.P. (2012). Metodologicheskie vozmozhnosti sotsial'noi (kul'turnoi) antropologii dlia sovremennykh kul'turnykh issledovanii [Methodological possibilities of social (cultural) anthropology in contemporary cultural studies]. Filosofia i kul'tura (Philosophy and culture), (10), $9-18$.

44. Koptseva, N.P. (2012). Problema metodologii sovremennykh kul'turnykh issledovanii: vozmozhnosti klassicheskoi britanskoi sotsial'noi antropologii [Problem of methodology for 
contemporary cultural studies: possibilities of classic British social anthropology]. Gumanitarnye $i$ sotsial'nye nauki (Humanities and social sciences), (4), 89-104.

45. Koptseva, N.P. (2013). Problema istiny v filosofii religii. Spetsifika kontseptualizatsii istiny v buddiiskoi filosofii [Problem of truth in the philosophy of religion. Specificity of truth conceptualization in Buddhist philosophy]. Filosofiia i kul'tura (Philosophy and culture), 11, 1564-1573.

46. Koptseva, N.P. Filosofiia i iskusstvo: edinstvo myslitel'nogo prostranstva [Philosophy and art: unity of the thinking space]. Uchenye zapiski fakul'teta iskusstvovedeniia i kul'turologii (Memoirs of Faculty of Arts and Culture Studies), Krasnoyarsk, 2000.

47. Koptseva, N.P., Libakova, N.M. (2013). Produktivnost' gendernogo podkhoda dlia gumanitarnykh issledovanii [Productivity of gender approach for humanitarian studies]. Sovremennye problemy nauki i obrazovaniia (Modern problems of science and education), (1).

48. Koptseva, N.P., Luzan, V.S. Gosudarstvennaia kul'turnaia politika v Sibirskom federal'nom okruge: kontseptsii, problem, issledovaniia: monografiia [State cultural policy in the Siberian Federal District: concepts, issues, research: monograph]. Krasnoyarsk, 2012.

49. Koptseva, N.P., Nevol'ko N.N. (2012). Vizualizatsiia etnicheskikh traditsii v zhivopisnykh i graficheskikh proizvedeiiakh khakasskikh masterov [Visualization of ethnic traditions in painting and graphic works of Khakassian masters]. Iskusstvo i obrazovanie (Art and education), (1), 27.

50. Koptseva, N.P., Nozdrenko, Ie.A. (2012). Etnopedagogicheskie podkhody v Sibirskom federal'nom universitete: ideia severnoi shkoly dlia korennykh narodov Severa, Sibiri i Dal'nego Vostoka [Ethnopedagogical approaches in Siberian Federal University: an idea of a northern school for the indigenous peoples of the North, Siberia and Far East]. Innovatsii v nepreryvnom obrazovanii (Innovations in continuing education), 5(12), 5-11.

51. Koptseva, N.P., Sertakova, Ie.A., Il'beikina, M.I., Zamaraeva, Iu.S., Libakova, N.M., Luzan, V.S. et al. Kul'tura korennykh i malochislennykh narodov Severa v usloviiakh global'nykh transformatsii: monografiia [Culture of the indigenous and small-numbered peoples in the context of global transformations: monograph]. St. Petersburg: Eidos, 2011, 174p.

52. Koval'chuk, N. (2008). Prikosnut'sia k prekrasnomu [Touch the beautiful]. Taimyr, (45), 7.

53. Krivonogov, V.P. Narody Taimyra (sovremennye etnicheskie protsessy) [Peoples of Taimyr (contemporary ethnic processes)]. Krasnoyarsk: RIO KSPU, 2001.

54. Krivonogov, V.P. Narody Taimyra v nachale XXI veka [Peoples of Taimyr at the beginning of the $21^{\text {st }}$ century]. Krasnoyarsk: RIO KSPU, 2007.

55. Kudinova, O.S., Belov, M.S. (2012). Istoriia razvitiia tobol'skoi rez'by po kosti [History of the development of the Tobolsk bone carving]. V mire nauchnykh otkrytii (In the world of scientific discoveries), (11), 191-201.

56. Lavrinov, D.G. Dinamika etnokul'turnoi identichnosti v usloviiakh globalizatsii [Dynamics of ethnic and cultural identity in the context of globalization]. Thesis for Candidate of Philosophical Sciences. M., 2008, 24-25.

57. Libakova, N.M. Modifikatsii gendernykh obrazov v rossiiskoi kul'ture kontsa XIX - nachala XXI vekov [Modification of gender images in the Russian culture from the end of the $19^{\text {th }}$ century to the beginning of the $21^{\text {st }}$ century]. Thesis for Candidate of Philosophical Sciences. Specialty: 24.00.01. Krasnoyarsk, 2011, 155p. 
58. Lur'e, S.V. Istoricheskaia etnologiia [Historical ethnology]. Moscow, Aspect-Press, 1997, 448 p.

59. Luzan, V.S. (2013). Konteksty ponimaniia intellektual'nogo dosuga $\mathrm{v}$ sovremennykh rossiiskikh issledovaniiakh [Contexts of intellectual leisure interpretation in modern Russian studies]. Bulletin of Krasnoyarsk State Pedagogical University named after V.P. Astafyev, 4 (26), 175-178.

60. Luzan, V.S. Sotsial'no-filosofskii analiz dinamiki gosudarstvennoi kul'turnoi politiki Rossiiskoi Federatsii [Socio-philosophical analysis of the dynamics of state cultural policy of the Russian Federation]. Thesis for Candidate of Philosophical Sciences. Specialty: 09.00.11. Krasnoyarsk, 2011, 170p.

61. Malakhov, V.S. (1998). Neudobstva s identichnost'iu [Inconvenience with identity]. Voprosy filosofii (Problems of philosophy), 2, 43-53.

62. Mikliaeva, A.V., Rumiantseva, P.V. Sotsial'naia identichnost' lichnosti: soderzhanie, struktura, mekhanizmy formirovaniia [Social identity of peersonality: content, structure, mechanisms of formation]. St. Petersburg, RSPU named after A.I. Herzen, 2008, 118p.

63. Mitlianskaya, T.B. Kholmogorskaia reznaia kost' [Kholmogory carved bone]. Arkhangelsk, 1991, 94p.

64. Morley, D. (2001). Belongings: Place, space and identity in a mediated world. European Journal of Cultural Studies, 4(4), 425-448.

65. Moskaliuk, M.V. Vsio, chto v serdtse. Khudozhniki Krasnoiaria vchera, segodnia, zavtra [Everything that is in my heart. Artists of Krasnoyarsk yesterday, today and tomorrow]. Krasnoyarsk: Polikor, 2010.

66. Musina, Ie.S. (2011). Razvitie iskusstva rez'by po kosti na Taimyre [Development of bone carving art on the Taimyr Peninsula]. Taimyrskie chteniia (Taimyr readings), (1), 37-47.

67. Narodnye mastera. Traditsii i shkoly [Follk artists. Traditions and schools]. Compiled and edited by M.A. Nekrasova. Moscow, 2006, 431p.

68. Naumenko, O.N. (2010). Kostoreznaia skul'ptura Tobol'ska kak sintez khudozhestvennykh traditsii Zapadnoi Sibiri [Bone carving sculpture in Tobolsk as a synthesis of the artistic traditions of Western Siberia]. Globalizatsiia: mify i real'nost': materialy Mezhdunarodnoi Nauchno-prakticheskoi konferntsii (Globalization: myths and reality: Proceedings of the Intern. scientific-practical conf. (Novemer, 24, 2010)), 172-175.

69. Nikaeva, T.M. (2013). Etnicheskie stereotypy v obraze mira russkikh, iakutov, evenkov i evenov [Ethnic stereotypes in the worldview of the Russians, Yakuts, Evenkis and Evens]. Bulletin of North-Eastern Federal University named after M.K. Ammosov, 10(3), 75-81.

70. Nikonova, A.A. (2009). Kul'turnoe nasledie i formirovanie identichnosti [Cultural heritage and identity formation]. Bulletin of St. Petersburg University. Series 6: Philosophy. Culture Studies. Politics. Law. International relations, (2), 203-209.

71. Otiutskii, G.P. Istoriia sotsial'noi (kul'turnoi) antropologii: ucheb.posobie dlia vuzov [History of social (cultural) anthropology: textbook for higher education]. Moscow, 2003, 347p.

72. Pavlenko, VI (2000). Predstavleniia o sootnoshenii sotsial'noi i lichnoi identichnosti v sovremennoi zapadnoi psikhologii [Representations of the relationship between social and personal identity in contemporary Western psychology]. Voprosy psikhologii (Problems of psychology), 1, 135-142. 
73. Perez, R.M. (2005). Towards a definition of politico-ideological practices in the prehistory of Minorca (the Balearic islands): The wooden carvings from Mussol Cave. Journal of Social Archaeology, 5(2), 276-299.

74. Popova, G.S. (2013). Etnokul'turnaia identifikatsiia v usloviiakh sovremennogo sotsiuma [Ethno-cultural identity in today's society]. Soveremennye issledovaniia sotsial'nykh problem (Modern studies of social problems (electronic scientific journal)), (2/22), 40.

75. Popova, U. (2013). Conservation, Traditional Knowledge, and Indigenous Peoples. American Behavioral Scientist, 58(1), 197-214.

76. Pozdniakova, O.A., Reznikova, K.V. (2013). Osobennosti sub'ektov khudozhestvennoi kinokommunikatsii [Features of subjects in artistic cinema communication]. Sovremennye problemy nauki i obrazovaniia (Modern problems of science and education), (4), 385p.

77. Predovskaia, M.M. Modifikatsiia i transformatsiia kul'turnoi identichnosti [Modification and transformation of cultural identity]. Thesis for Candidate of Philosophical Sciences. St.Petersburg, $2009,60 \mathrm{p}$.

78. Reznikova, K.V. (2013). Znachenie kinematografa dlia formirovaniia obshcherosiiskoi natsional'noi identichnosti [Value of cinema for the formation of all-Russian national identity]. Sovremennye problemy nauki i obrazovaniia (Modern problems of science and education), 3, $416 \mathrm{p}$.

79. Reznikova, K.V. Sotsial'noe konstruirovanie obshchenatsional'noi identichnosti v Rossiiskoi Federatsii [Social construction of national identity in the Russian Federation], Summary of Thesis for Candidate of Philosophical Sciences. Specialty: 09.00.11. Krasnoyarsk, 2012, 20p.

80. Robbins, J. (2010). A nation within? Indigenous peoples, representation and sovereignty in Australia. Ethnicities, 10(2), 257-274.

81. Rodionov, G.N. (2009). Pedagogicheskie usloviia tvorcheskogo razvitiia shkol'nikov v kruzhke "Iunyi kostorez" [Pedagogical conditions of pupils' creative development in a circle "Young Bone Carver"]. Bulletin of RSPU named after A.I. Herzen, (91), 144-147.

82. Rogachev, S.V. (2012). V poiskakh granitsy Tsentral'noi Rossii. Varnavinskaia khudozhestvennaia rez'ba po kosti (Nizhegorodskoe Zavolzhie) [Finding borders of Central Russia. Varnavinsky bone carving (Nizhny Novgorod - Zavolzhye)]. Geografiia - Pervoe sentiabria (Geography - First of September), (7), 42-54.

83. Rybnikova, O.P., Tikhomirov, S.A. (2013). IN MEMORIAM. Nikolai D. Butorin (19342013). Voprosy kul'turologii (Problems of culture studies), (8), 101-104.

84. Semenova, A.A. (2012). Vizual'naia kul'tura modernizovannogo sotsiuma [Visual culture in modernized society]. Bulletin of Volgograd State University. Series 7. Philosophy, sociology and social technologies, (3), 141-149.

85. Semenova, A.A. Modifikatsii drevnerusskogo kontsepta "gosudarstvo" v rossiiskoi kul'ture XXI veka: metodologicheskii aspekt [Modification of ancient concept of "state" in Russian culture of the $21^{\text {st }}$ century: methodological aspect]. Thesis for Candidate of Philosophical Sciences. Specialty: 24.00.01. Krasnoyarsk, 2009, 198p.

86. Semenova, A.A., Gerasimova, A.A. (2013). Osobennosti tvorcheskogo metoda Sergeia Anufrieva [Features of Sergei Anufriev's creative method]. Sovremennye problemy nauki i obrazovaniia (Modern problems of science and education), (2), 542.

$$
-765-
$$


87. Sertakova, Ie.A. (2010). Funktsionirovanie proizvedenii iskusstva v seti Internet [Works of art on the Internet]. Nauka i sovremennost' (Science and modernity), (3-1), 64-68.

88. Sertakova, Ie.A. (2012). Kul'turnaia geografiia A. Lefevra v svete gumanitarnykh issledovanii sotsial'nogo prostranstva goroda [Culture geography of H. Lefebvre in the light of humanitarian researches of social space of the city]. Teoriia i praktika obshchestvennogo razvitiia (Theory and practice of social development), (3), 24-26.

89. Sertakova, Ie.A. (2013). Issledovanie "goroda" v klassicheskikh kontseptsiiakh zarubezhnykh uchianykh [Study of "city" in classical concepts of foreign scientists]. Sovremennye problemy nauki i obrazovaniia (Modern problems of science and education), (4), 381.

90. Severnaia reznaia kost' [Northern carved bone]. Album, texts and imageg by I. Vyshar). Moscow, 2003, 175p.

91. Shchurov, G.S. (2004). Ocherki istorii kul'tury Russkogo Severa 988-1917 [Essays on the history of culture of the Russian North from 988 to 1917]. Arkhangelsk, 551p.

92. Shetler, J.B. (2010). Historical memory as a foundation for peace: Network formation and ethnic identity in North Mara, Tanzania. Journal of Peace Research, 47(5), 639-650.

93. Simonova, O.A. (2008). K formirovaniiu sotsiologii identichnosti [On formation of identity sociology]. Sotsiologicheskii zhurnal (Journal of sociology), 3, 45-61.

94. Solov'iova, A.N. (2009). Kul'turnye razlichiia kak osnova etnicheskoi identichnosti $\mathrm{v}$ kontekste globalizatsii [Cultural differences as the basis of ethnic identity in the context of globalization]. Mir psikhologii (World of psychology), (3), 23-34.

95. Solov'iova, A.N. (2011). "Etnicheskaia subkul'tura": kontseptualizatsiia etnichnosti v kontekste kul'turnykh razlichii ["Ethnic subculture": conceptualization of ethnicity in the context of cultural differences]. Mezhdunarodnyi zhurnal issledovanii kul'tury (International journal of culture studies), (1), $6-14$.

96. Solov'iova, I. (2006). Rez'ba po kosti [Bone carving]. Narodnoe tvorchestvo (Folk art), (6), 30-34.

97. Stefanenko, T.G. Etnopsikhologiia: ucheb. dlia vuzov [Ethnopsychology: textbook for higher education]. Moscow: Aspect-Press, 2003, 210p.

98. Subbotina, V.A. (2012). Tobol'skaia rez'ba po kosti v kontekste sotsrealizma [Tobol'sk bone carving in the context of social realism]. Bulletin of Ural Federal University. Series 2: Humanities, 93(3), 105(3), 213-223.

99. Subbotina, V.A. (2011). Khudozhestvenno-stilevoe svoeobrazie tobol'skoi rez'by po kosti [Original art and style in Tobolsk bone carving (860 - 1917)]. Bulletin of Ural Federal University. Series 2: Humanities, 93(3), 171-177.

100. Svas'ian, K.A. Chelovek v labirinte identichnostei [A man in a maze of identities]. Moscow: Evidentis, 2009, 187p.

101. Sweet, E.L., Chakars, M. (2010). Identity, Culture, Land, and Language: Stories of Insurgent Planning in the Republic of Buryatia, Russia. Journal of Planning Education and Research, 30(2), 198-209.

102. Taimyrskaia reznaia kost' [Taimyr carved bone], (art album), Dudinka, Krasnoyarsk, 2008, 151 p.

103. Taylor, D.M., Usborne, E. (2010). When I Know Who 'We' Are, I Can Be 'Me': The Primary Role of Cultural Identity Clarity for Psychological Well-Being. Transcultural Psychiatry, 47(1), 93111. 
104. Ukhanova, I.N. Severnorusskaia reznaia kost' XVII-XIX vekov [Carved bone of Russia North during 17-19 centuries], St. Petersburg, 2005, 176p.

105. Ulturgasheva, N.T. (2010). Osobennosti sovremennykh issledovanii traditsionnoi kul'tury narodov Sibiri [Features of modern research of Siberian traditional culture]. Bulletin of Kemerovo State University of Culture and Arts, (13), 39-48.

106. Valov, A.A. Tobol'skaia reznaia kost' [Carved bone in Tobolsk], Sverdlovsk, 1987, 191p.

107. Velichko, N.I. (2010). Etnichnost' kul'tury kak predmet etnokul'turnogo issledovaniia [Ethnicity of culture as an object of ethno-cultural study]. Obshchestvo. Sreda. Razvitie. (Society. Enironment. Development) (TerraHumana), (3), 198-201.

108. Vinokurova, Ie.P. (2008). Kul'turnye vozmozhnosti etnosa [Ethnic cultural opportunities]. Proceedings of Russian State Pedagogical University named after A.I. Herzen, (70), 122-125.

109. Vladislavleva, T.B. (2011). Kul'turno-istoricheskoe nasledie kak resurs innovatsionnogo razvitiia korennykh malochislennykh narodov Severa [Cultural and historical heritage as a resource for innovative development of the indigenous peoples of the North]. Bulletin of Moscow State Linguistic University, (608), 9-20.

110. Volzhanina, Ie.A. (2009). Sovremennye etnosotsial'nye protsessyy sredi nentsev Yamala $\mathrm{v}$ usloviiakh promyshlennogo osvoenia [Modern ethnosocial processes of the Yamal Nenets during industrial development]. Problemy istorii, filologii, kul'tury (Problems of history, philology, culture), (25), 355-358.

111. Vostriakov, L.Ie., Lapteva, G.Ia. (2012). Kul'tura Russkogo Severa: traditsii sokhraneniia i problemy ispol'zovaniia [Culture of the Russian North: tradition of conservation and problems of usage]. Sovremennaia nauka: Aktual'nye problemy teorii i praktiki. Seriia "Gumanitarnye nauki". (Modern science: Actual problems of theory and practice. Series: "Humanities"), (7-8), available at: http://www.vipstd.ru/nauteh/index.php/--gn12-07/597.

112. Willis, R.H. (1964). Finnish Images of the Northern Lands and Peoples. ActaSociologica, 7(2), 73-88.

113. Zamaraeva, Iu.S. (2010). Aktual'nost' issledovaniia otnosheniia migrant i prinimiushchei sredy $\mathrm{v}$ sovremennoi filosofii kul'tury [Relevance of research on the relationship between a migrant and the host environment in the modern philosophy of culture]. Nauka i sovremennost' (Science and Modernity), (5-3), 96-100.

114. Zavarzina, V.G. (2008). V aure tvorchestva - sodruzhestvo kostorezov [In the aura of creativity - community of bone carvers]. Taimyr, (148), 5.

115. Zavarzina, V.G. (2010). Kostoreznaia pesnia Taimyra [Bone carving song of Taimyr]. Taimyr, (38), 5-8.

116. Zavarzina, V.G. (2011). "Bereg taimyrskoi kosti" v Krasnoiarske ["Taimyr Bone Coast" in Krasnoyarsk]. Etno-mir. O narodakh Krasnoiarskogo kraia (Ethnic World. On peoples of the Krasnoyarsk Territory), (5), 49-52.

117. Zavarzina, V.G. (2011). Iubileinyi sliot kostorezov [Jubilee gathering of bone carvers]. Taimyr, (113), 4-5.

118. Zavarzina, V.G. (2011). Nesluchainyi interes [Not occasional interest]. Taimyr, (6), 6.

119. Zavarzina, V.G. (2011). Tvorcheskaia laboratoriia "taimyrskaia reznaia kost" (Creative Laboratory "Taimyr carved bone"). Taimyr, (100), 4-5. 
120. Zavarzina, V.G. (2013). "Dusha Severa" - taimyrskaia dusha ["The soul of the North" Taimyr soul]. Taimyr, (2), 1.

121. Zhukovsky, V.I., Koptseva N.P. Propozitsii izobrazitel'nogo iskusstva [Propositions of art]. Krasnoyarsk, 2004, 266p.

122. Zhukovsky, V.I., Koptseva, N.P., Pivovarov D.V. Vizual'naia sushchnost' religii [Visual essence of religion]. Krasnoyarsk, 2006, 461p.

\title{
Формирование этнической идентичности \\ индигенных народов Севера \\ в декоративно-прикладном искусстве \\ на примере искусства косторезов
}

\author{
Н.М. Либакова, Е.А. Сертакова \\ Сибирский федеральный университет \\ Россия, 660041, Красноярск, пр. Свободньій, 79
}

\begin{abstract}
Вопрос о формировании этнической идентичности особенно актуален для представителей индигенных народов, поскольку в настоящее время в условиях глобальных трансформачий под воздействием «больших культур» всё сложнее сохранять уникальность традиционных культур. Но в то же время внутри самой культуры существует множество механизмов, позволяюших формировать и поддерживать этническую идентичность. Одним из таких механизмов является декоративно-прикладное искусство. В статье на материале анализа произведений косторезов Севера Красноярского края раскрываются возможности этого вида искусства в деле сохранения традиционых иенностей культуры, формирования этнической идентичности современных представителей индигенных народов.
\end{abstract}

Ключевые слова: индигенные народы, коренные малочисленные народы Севера, этническая идентичность, культурные исследования, декоративно-прикладное искусство, резьба по кости.

Научная специальность: 24.00.00 - культурология, 17.00.00-искусствоведение. 